\title{
THE MEASUREMENT OF GASTRIC ACID
}

\author{
J. H. LAwrIE, M.B.Glasg., F.R.C.S., F.R.C.S.E., D.C.H. \\ A. P. M. Forrest, M.D., Ch.M., B.Sc., (St. And.), F.R.C.S., F.R.C.S.E., F.R.C.S. (Glasg.)
}

Department of Surgery, Welsh National School of Medicine and United Cardiff Hospitals.

Human gastric juice contains water, hydrochloric acid, pepsin, intrinsic factor, mucus and electrolytes. Of these, hydrochloric acid has been studied most extensively by the clinical investigator-partly because of the likely association of its erosive powers with the development of peptic ulceration, and partly because of the apparent simplicity of its estimation.

\section{Test Meals}

Since the end of the last century the standard method of assessing gastric acid secretion has been by the test meal, which was developed largely by von Leube (1876), Ewald and Boas (1885) and Rehfuss (1927). Its history and development have been reviewed by Hollander and Penner (1939) and Rovelstad (1963). The vast amounts of data collected in these original studies contributed only little to our knowledge of the secretions of the stomach in health and in disease. With the recent development of precise quantitative methods of assessing gastric function, such investigations are now largely of historical interest.

The 'fractional test meal', still performed today, differs little from that described by Rehfuss in 1914. Following a fast, a gastric tube is passed and the stomach emptied. A 'test meal' of carbohydrate-bread, cereal, gruel or biscuits, is ingested and $10 \mathrm{ml}$. of gastric juice aspirated each 15 minutes for 2-3 hours. The acidity in each sample is estimated by titration with $0.1 \mathrm{~N} \mathrm{NaOH}$ using two indicators - Topfer's dimethylaminoazobenzene for 'free', and phenolphthalein for 'total' acid. The acidity curve is drawn on a chart which shows a 'normal range' based on the curves of 80 of the 100 normal students studied by Bennett and Ryle in 1921. It is of interest that the other 20 students showed curves from extreme hypo- to hypersecretion.

The fractional test meal has little to commend it as a test of gastric function. It is neither precise, quantitative nor reproducible The coefficient of variation of the concess tration of free acid in a series of 20 consecutis meals performed on a healthy adult range from 25.8 to $199.6 \%$-quite outside acceptable limits (Bell and McAdam, 1924). It is theret fore not surprising that Enticknap and Merivale (1954), in an analysis of 1000 grue meals, concluded that they were of little diagnostic value. In a comparison with the augmented histamine test in 114 patients. Marks and Shay (1960) found that, althouge the peak acidity in a fractional test meal was statistically related to the acid output in atlot augmented histamine test, the results of a fest meal could not be used to predict the gुwere acid output in an individual patient.

As the 'test meal' was a poor stimulus $\overline{8 \mathrm{f}}$ gastric secretion, differing little from plafor water (Bergeim, Rehfuss and Hawk, 1914), the incidence of achlorhydria was fairly hig $\overline{\text {. }}$. More potent stimuli were used-alcohol (Kast. 1906; Ehrmann, 1912) caffeine (Katsch a a Kalk, 1924) and histamine, either in single (Bockus and Bank, 1927; Vanzant, Alvares, Eustermen, Runn and Berkson, 1932), double (Rivers, Osterby and Vanzant, 1936), or tripe (Hitchock, Sullivan and Wangensteen, 195\%) doses. However, even with a standard dose of histamine (usually $0.01 \mathrm{mg}$. histamine acid phosphate per $\mathrm{kg}$. body weight) the respons had a wide variation in normal subjects a proved of little routine diagnostic value (Poj:land and Bloomfield, 1931; Polland, 1933).

\section{Criteria of Tests of Acid Secretion}

\section{Collections}

The measurement of a secretory response requires an estimate of both the volume $\mathrm{f}$ juice secreted and its acidity. Therefore, the gastric tube must be placed so that all the juice secreted is withdrawn for analysis. 'Blinel' placement of gastric tubes is unsatisfactoony (Callender, Retief and Witts, 1960) and radis- 
logical screening is now generally considered to be an essential part of any test.

Efficient aspiration is necessary for complete collection of the juice secreted. Using a radioopaque marker as an index of complete aspiration, Johnston and McGraw (1958) found suction by syringe more efficient than by a pump, but continuous aspiration by lowpressure suction pump is now more generally used. This requires constant care to ensure that the tube remains unblocked-either by the repeated injection of air down the tube, or by the use of an 'air vent' in the pump or in the tube.

\section{Titration}

The concentration of acid in the specimens of gastric juice must be accurately estimated. Gastric juice, during adequate stimulation of secretion, has a $\mathrm{pH}$ of approximately 1.0. In this range of acidity the measurement of $\mathrm{pH}$ inaccurately reflects change in titratable acidity. For example, at $\mathrm{pH} 1$ a change of $0.1 \mathrm{pH}$ unit is equivalent to $26 \mathrm{mEq}$. $\mathrm{HCl} / \mathrm{l}$, while at a $\mathrm{pH}$ of 3 a change of $0.1 \mathrm{pH}$ unit represents a change of only $0.5 \mathrm{mEq}$. $\mathrm{HCl} / 1$ (James, 1957). The best means of determining acid concentration is by titration to 'neutrality'.

The concept of free and combined acid arose from a study of the responses to test meals (Prout, 1824; Michaelis, 1926) when a proportion of the acid is buffered by the ingested meal itself. The titration curve of the aspirated gastric juice resembled that of pure hydrochloric acid only in the range of $\mathrm{pH} 1-3$. It was assumed that titration to a $\mathrm{pH}$ of 2.8 3.0 could be attributed to 'free' hydrochloric acid. This was determined using Topfer's reagent (dimethylaminoazobenzene) which changes colour at this $\mathrm{pH}$. Further titration to neutrality followed a different curve and this was considered to be due to 'combined' acid, and estimated with phenolphthalein (colour change $\mathrm{pH}$ 8.0-10.0).

The titration curve of uncontaminated gastric juice does not, in fact, differ from that of hydrochloric acid and these terms should be abandoned in favour of total titratable acidity (Bock, 1962).

Accurate titration of gastric juice to neutrality is best performed electrometrically. With the universal availability of the glass-electrode $\mathrm{pH}$ meter this is simpler and more accurate than by the use of indicators (Berk, Thomas and Rehfuss, 1942). Although at $37^{\circ} \mathrm{C}$ the isoelectric point of $\mathrm{HCl}$ is $\mathrm{pH} 6.8$, in practice, titration to a $\mathrm{pH}$ of 7.0 is satisfactory.

\section{Expression of results}

Acidity is frequently expressed in terms of normality. As a normal solution of $\mathrm{HCl}$ contains $1000 \mathrm{mEq} / \mathrm{l}$, millinormality $(\mathrm{mN})$ can also be expressed as mEq./1. The 'clinical unit' still occasionally referred to is the $\mathrm{ml}$. $0.1 \mathrm{~N} \mathrm{NaOH}$ required to titrate $100 \mathrm{ml}$. of gastric juice. This is equivalent to the millinormality or the number of milliequivalents per litre.

The output of acid secreted by the stomach in $\mathrm{mEq}$./unit time (usually one hour) is the product of the volume (in litres) and the concentration (in mEq./1).

\section{Secretory rate}

Apart from the accuracy in collection and estimation of acidity, the output of acid determined is dependent upon the rate of secretion and therefore upon the degree of stimulation of the parietal cells, which may vary from a basal state to one of maximal secretory activity.

\section{Basal Secretion}

In man it is difficult to achieve truly basalo conditions. Psychogenic factors are known to stimulate, through the vagus, acid gastric secretion. Basal juice may be collected overnight (Levin, Kirsner, Palmer and Butler, 1948a; Sandweiss, Friedman, Sugarman and Podolsky, 1964a and b; Johnson, 1962) or as a timed collection after an overnight fast (Levin, Kirsner and Palmer, 1950). In general patients with duodenal ulcer have a higher unstimulated acid output than normals, but there is a wide overlap. Considerable day to day variation also occurs in individual patients (Levin, Kirsner, Palmer and Butler, 1948b).

Very high levels of basal secretion (a basal 1-hour secretion of $15 \mathrm{mEq}$. $\mathrm{HCl}$ or more, or a 12-hour night secretion of 2 litres and $120 \mathrm{mEq}$. (Sircus, 1962) ) should always raise the suspicion of a Zollinger-Ellison tumour.

\section{Stimulated Secretion}

\section{The augmented histamine test}

Histamine strongly stimulates acid gastric secretion in experimental animals (Popielski, 1920) and in man (Carnot, Koskowski and Liebert, 1922). Increasing doses produce an increasing response and Kay (1953) has shown that a single dose of $0.04 \mathrm{mg}$. histamine acid phosphate per $\mathrm{kg}$. body weight will induce 'maximal' secretion. The side effects of a dose 


$$
\begin{array}{ll}
\text { patient A.M.C. } & - \text { output } \mathrm{HCl} \\
& \ldots . . \text { volume juice } \\
\text { augmented histamine test } & \text { histamine infusion }
\end{array}
$$

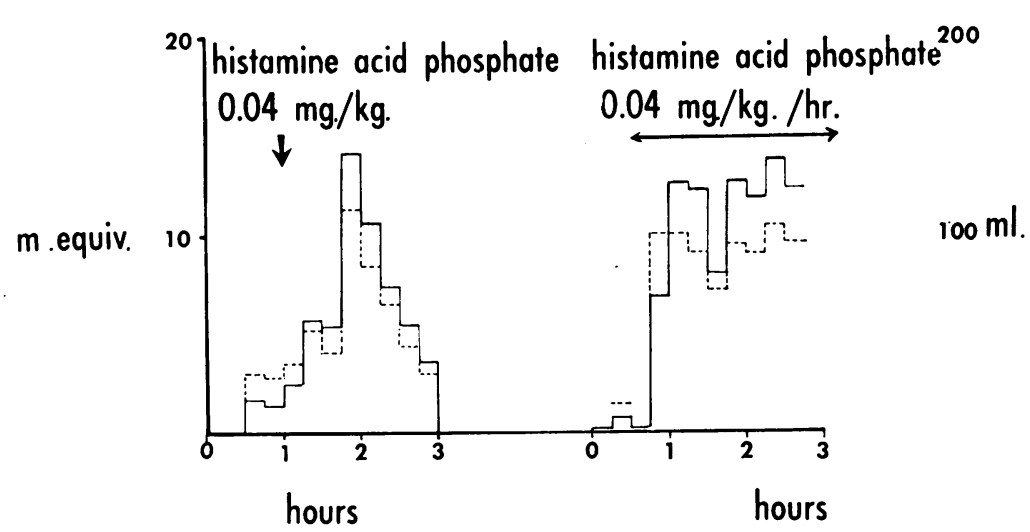

FIG. 1.-Augmented histamine test-acid output per 15 minutes, with an infusion test in the same patient.

of this magnitude are prevented by the prior administration of an anti-histamine which is without effect on the action of histamine on the parietal cell (Conrad, Kowalewski and Geertruyden, 1949; Kay, 1953).

Following intubation of the patient the basal secretion is collected and $100 \mathrm{mg}$. mepyramine maleate given intramuscularly after 30 minutes. Thirty minutes later (i.e. after one hour of basal collection) histamine acid phosphate, $0.04 \mathrm{mg} . / \mathrm{kg}$. body weight, is injected subcutaneously and collections contained for four 15 -minute periods. The volume and acidity of each specimen is estimated and the output of $\mathrm{HC1}$ calculated in milliequivalents.

As this large dose of histamine induces total parietal cell activity, the response is related to the parietal cell mass (Card and Marks, 1960; Marks, Komarov and Shay, 1960). It is therefore reproducible and similar figures for normal individuals and patients with duodenal ulcer have been reported from different centres (Marks, 1961). Nevertheless, it is a transient response which reaches a peak normally during the second or third 15-minute period after the injection of histamine and then declines to basal levels (Fig. 1). Thus, though the dose of histamine used induces maximum secretion, this is only achieved for a limited period of time within the total response.

Various workers have used different com- binations of the 15-minute collection to express the results. These are usually quoted as the output of $\mathrm{HCl}$ in $\mathrm{mEq}$./hour. The ave output of acid in normal subjects is $22-3$ $\mathrm{mEq}$./hour and that for patients with duodemal ulcer 37-40 mEq./hour (Marks, 1961).

\section{Histamine infusion test}

Many of the shortcomings of the augmentêㄹ histamine response can be overcome if a steady state of secretory activity is induced by continuous infusion of histamine. In dogs, this stimulus has been widely used to study the function of gastric pouches but few repots have been made on its use in man (Ada角, Card, Riddell, Roberts, Strong and Wooff, 1954; Hirschowitz, Londop and Wiggins, 1957). By performing dose-response curves using this stimulus we have shown that a maximal platean can be obtained with a dose of histamine a ad phosphate of $0.04 \mathrm{mg}$. $/ \mathrm{kg}$. body weight $/$ hot (Lawrie, Smith and Forrest, 1964).

With the recent availability of pre-sterilised plastic equipment and slow-injection infusiegt pumps, a histamine infusion can now be used for the routine assessment of the secretion $\Leftrightarrow \mathrm{f}$ gastric acid in man. The administration of this relatively small dose of histamine by continuols intravenous infusion, though inducing maximgl response from the stomach, elicits fewer sideeffects than a single large dose. A small doge of anti-histamine (25-50 mg.) adequately mi 


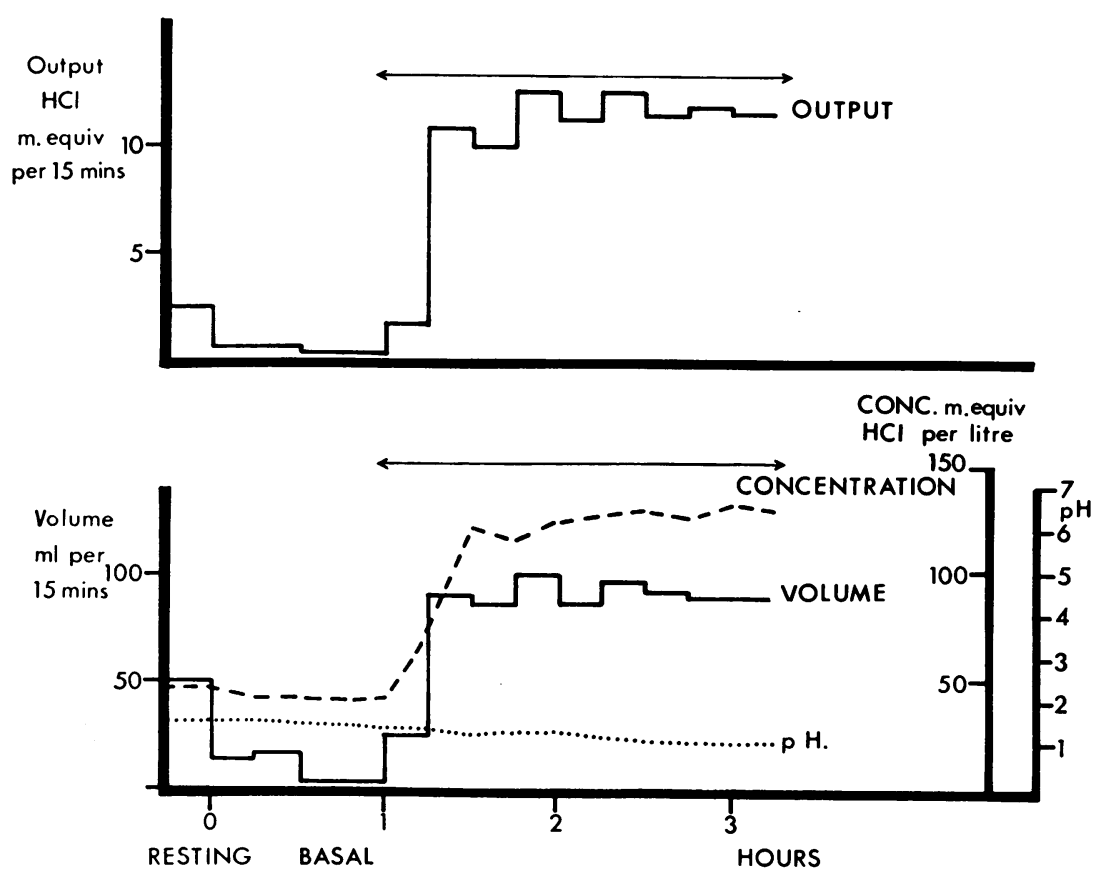

FIG. 2.-Histamine infusion test.

gates these side-effects. Further, the side-effects of histamine pass off soon after the intravenous infusion has been stopped. Outpatients are little upset by the test and are able to return to work immediately.

Nasogastric intubation of the patient is carried out in the normal way and continuous suction applied with the patient flat on his left side. A small pædiatric scalp vein needle is inserted into an antecubital vein and $25 \mathrm{mg}$. of mepyramine maleate injected. A solution of histamine acid phosphate in saline is then delivered by slow-infusion pump to give a dose of $0.04 \mathrm{mg}$. per $\mathrm{kg}$. body weight per hour (Lawrie and others, 1964).

The volume of gastric juice and its acidity rise during a period of about 30-45 minutes following the start of the infusion. Thereafter the 15-minute aspirations maintain a fairly constant volume and acidity and this 'plateau' response can be maintained for many hours (Fig. 2). Four successive 15-minute specimens of similar volume and acidity constitute a onehour maximal output at this steady secretory rate.
It has been shown that the test is reproducible (Fig. 3) and in one patient recently studied the hourly outputs of $\mathrm{HCl}$ on four separate occasions were $42.3,41.8,37.9$ and $39.2 \mathrm{mEq}$. In a comparison of the response of histamine infusions and augmented histamine tests in 45 patients, it was also shown that the hourly output of acid during the infusion of 3 histamine was significantly greater than that in 8 the augmented histamine response (Fig. 4) (Lawrie and others, 1964).

An incidental advantage of the histamine infusion test is that errors arising from incomplete aspiration of gastric contents are

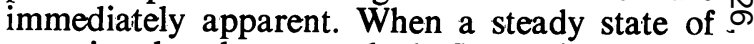
secretion has been reached, fluctuation in the $N$ volume of the 15-minute collections indicates $\underset{\mathrm{N}}{\mathrm{N}}$ that the tube is badly placed or blocked. As 0 the test is continued until four successive 15minute collections are of equal value, the result is not jeopardised by such adjustments.

$\mathrm{X}$-ray studies following the injection of a radio-opaque substance have confirmed that, with the patient on his left side, the maintenance of a plateau indicates satisfactory tube 


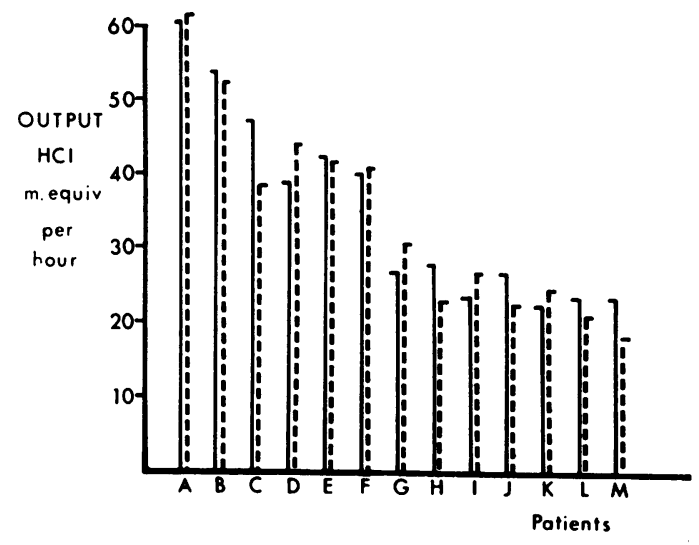

FIG. 3.-Duplicate histamine infusion tests in 13 patients. (Lawrie et al., 1964). Reproduced by permission of the Editor of The Lancet.

\section{Continuous \\ Histamine \\ Infusion}

0.04 mg. per

kg. per hour.

Augmented

Histamine

$0.04 \mathrm{mg}$. per $\mathrm{Kg}$.
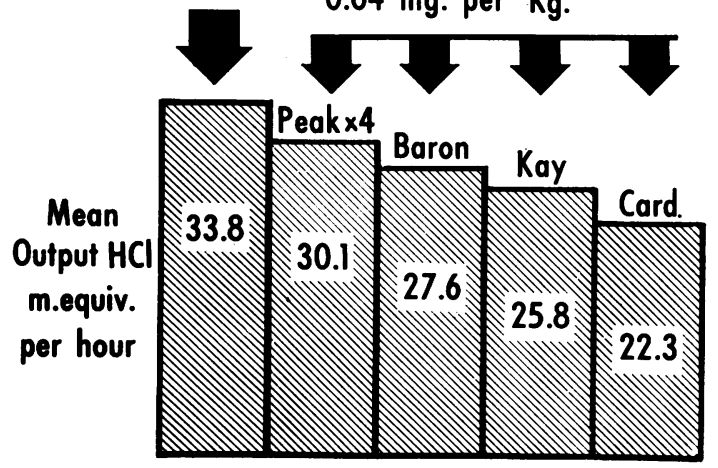

Fig. 4.-Comparison of mean output from 45 infusion tests with augmented histamine responses in patients. These have been interpreted as (1) Peak 15-minute x 4; (2) two highest successive 15-minute peaks (Baron, 1963b); (3) 15-45 minutes $x 2$ (Kay, 1953); and (4) 0-60 minutes. (Card and Marks, 1960)-(from Lawrie, et al., 1964). Reproduced by permission of the editor of The Lancet.

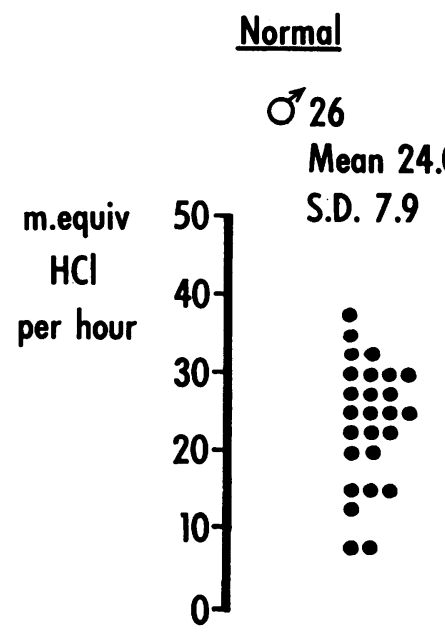

Fig. 5.-Results of histamine infusion test in 49 normal subjects.

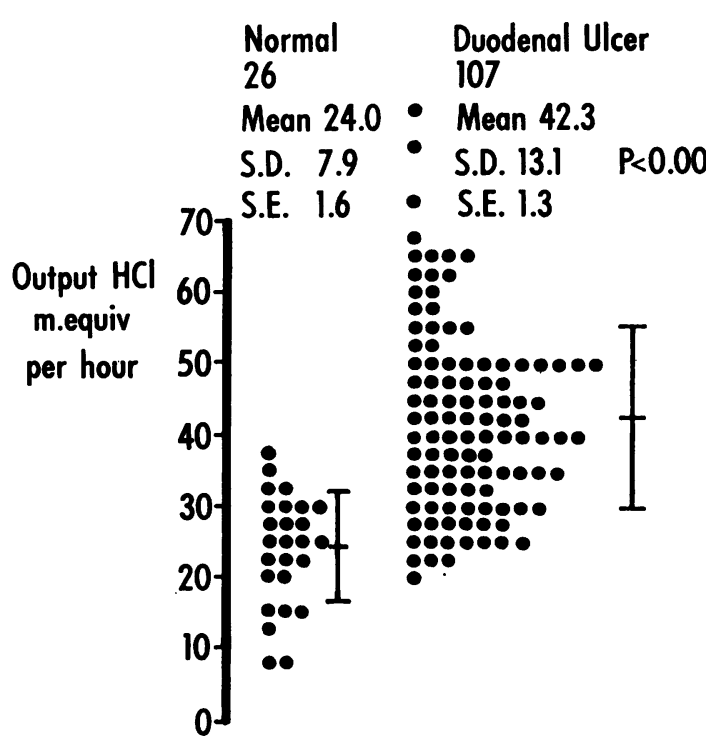

FIG. 6.-Results of histamine infusion test in patients with duodenal ulcer.
$23 \frac{\bar{c}}{\vec{\sigma}}$

S.D. 4.2

$P>0.1$

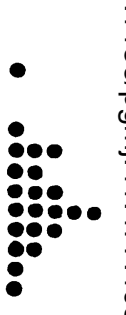




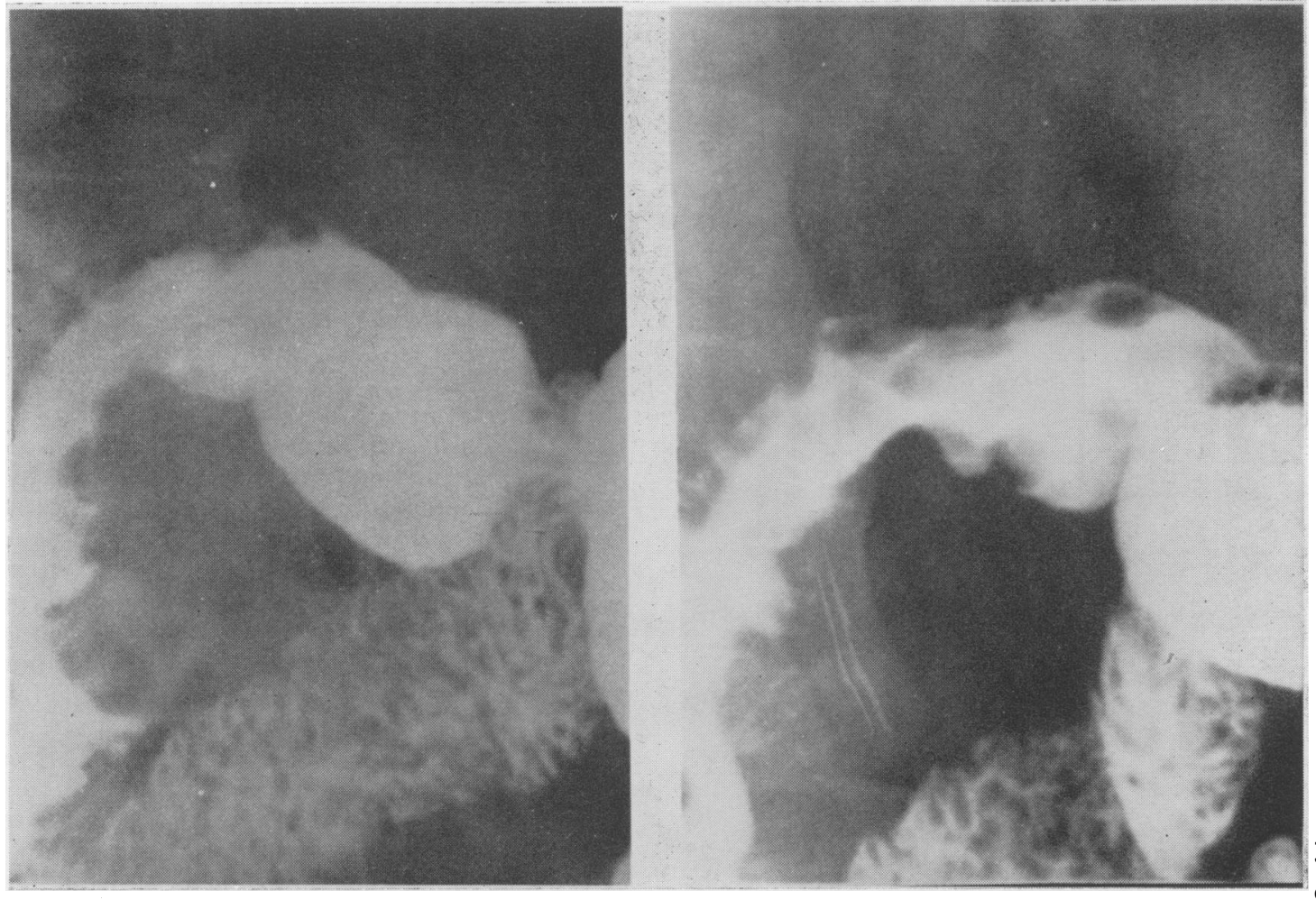

FIG. 7.-Coarse mucosal folds in duodenum shown in the supine position on the right, with the folds obliterated by filling the duodenal cap on the left.

position. As a result, screening of the patient is an unnecessary addition.

During the past two years this test has been used routinely to study gastric function in our laboratories. The results can be summarised as follows:

Normal response. The mean acid output and its standard deviation of 26 normal men and of 23 normal women was $24.0 \pm 7.9$ and $21.0 \pm 4.2 \mathrm{mEq}$./hour respectively (Fig. 5). In contrast with other studies, in which men have had a higher output (Baron, 1963) these means are not significantly different. In our series of normal subjects, acid output falls with advancing age. Again, in contrast to the findings of others using the augmented histamine test (Baron, 1964) no correlation with body weight was observed.

Duodenal ulcer. The mean acid output in 107 male patients with proved duodenal ulcer was $42.3 \pm 13.1 \mathrm{mEq}$./hour. This is significantly different from that in normal men (Fig. 6). In the ulcer group the acid output was correlated neither with age nor body weight.

Duodenitis. During the past three years we have studied a group of 33 patients with a characteristic radiological abnormality described as 'coarse duodenal mucosal folds' (Fraser, Pitman, Lawrie, Smith, Forrest and Rhodes, 1964). The outstanding radiological feature is a cobblestone appearance of the mucosa of the first and sometimes also of the second part of the duodenum (Fig. 7). This is best seen in the supine position with the duodenum filled with air and coated with barium. Such patients have typical symptoms of peptic ulcer but no demonstrable ulcer.

The acid output of this group, estimated by the histamine infusion test, was $45.0 \pm 11.8$ $\mathrm{mEq}$./hour, a mean not significantly different from that of patients with duodenal ulcer (Fig. 8). The findings of Rhodes, Apsimon and 
Coarse Duodenal Normal Mucosal Folds

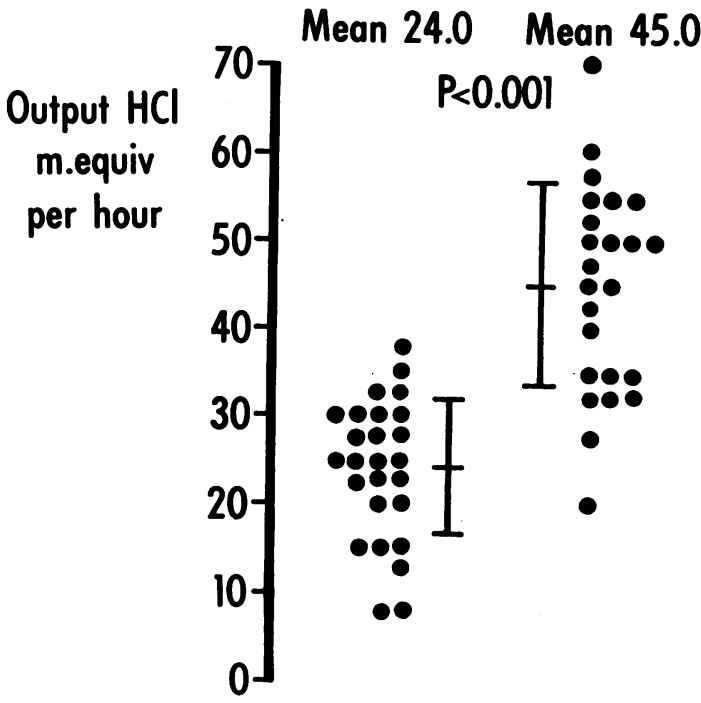

Fig. 8.-Results of histamine infusion test in 25 patients with coarse mucosal folds in the duodenum contrasted with those in 26 normal males.

Lawrie (1965) and of James (1964) also suggest that in these patients the acid environment in the duodenum is abnormally high.

Patients with this triad of (1) typical symptoms of peptic ulcer (2) a high acid output, and (3) coarse duodenal mucosal folds, cannot therefore be dismissed as functional. If their symptoms are severe and persistent, they merit definitive surgery, as for frank duodenal ulceration.

Gastric freezing. Serial histamine infusion tests were used to assess the effect of intragastric freezing (Wagensteen, Peter, Nicoloff Walder, Sosin and Bernstein, 1962) on parietal cell activity in 12 patients (Lawrie, Smith, Goodall, Pitman and Forrest, 1965). The results indicated that depression of secretion does not constantly occur. In two of the four patients in whom inhibition of secretion occurred, this was temporary and pre-treatment levels were regained within six months (Fig. 9).

Achlorhydria. The histamine infusion test has proved of particular value in conditions in which the output of acid is severely depressed. Hourly outputs of a few milliequivalents of $\mathrm{HCl}$ can be accurately assessed, allowing discrimination between those who are trufy achlorhydric and those in whom acid secretion is still present, albeit at a low level. For example, in iron-deficiency anæmia, a whole range of outputs from complete achlorhydria normal levels have been demonstrated. Previously, such patients have been regarded either 'normal' secretors or 'achlorhydric'.

Histalog

This analogue of histamine, a 3-beta aminoethyl pyrazole, stimulates acid gastrue secretion without the usual side effects of histamine. Large doses can therefore be give्g without antihistamine cover.

Maximal acid outputs can be induced by single subcutaneous injection of $200 \mathrm{mg}$. ang corretate well with those of the augmented histamine test (Ward, Gillespie, Passaro and Grossman, 1960). The slightly higher outputs noted with histalog may be due to the longe duration of its effect compared with histamine.

In the United States histalog, given by single injection, has been used to study acid gastric secretion in man (Kirsner and For 1955; Grossman, Kirsner and Gillespie, 1963t These responses to single injection have the same disadvantages mentioned in relation to the augmented histamine test. Further, क़े relatively high cost of histalog prevents widespread use in clinical practice.

\section{Gastrin}

With the extraction and isolation in pure form of the natural gastric secretory hormone gastrin. by Gregory and Tracy $(1961,1964) \bar{z}$ physiological stimulus is now available for test of gastric function. These workers have showo that a mixture of their two polypeptides, gastrii I and II, will elicit a steady state of acid outpuif from the stomach in dogs if given by repeate subcutaneous injection or continuous infusion The output of acid is proportional to the dose.

Studies in human subjects are, so far, few? The secretory response of the stomach of one human subiect to gastrin II has been intensivel investigated by Makhlouf, McManus and Card (1964a). Although gastrin II is a more potemi stimulus than histamine, the maximal secretor response provided by both stimuli is remarkablyo similar. In 16 subjects a linear relationship was found between the maximal acid outputs ine duced by the two drugs $(r=0.992)$. Althoug recently it has been suggested that the maximaf output induced by gastrin may be slightly higher than that by histamine (Makhloufo McManus and Card, 1964b), the highly signifi ? cant correlation between them suggests that the 
L.P.

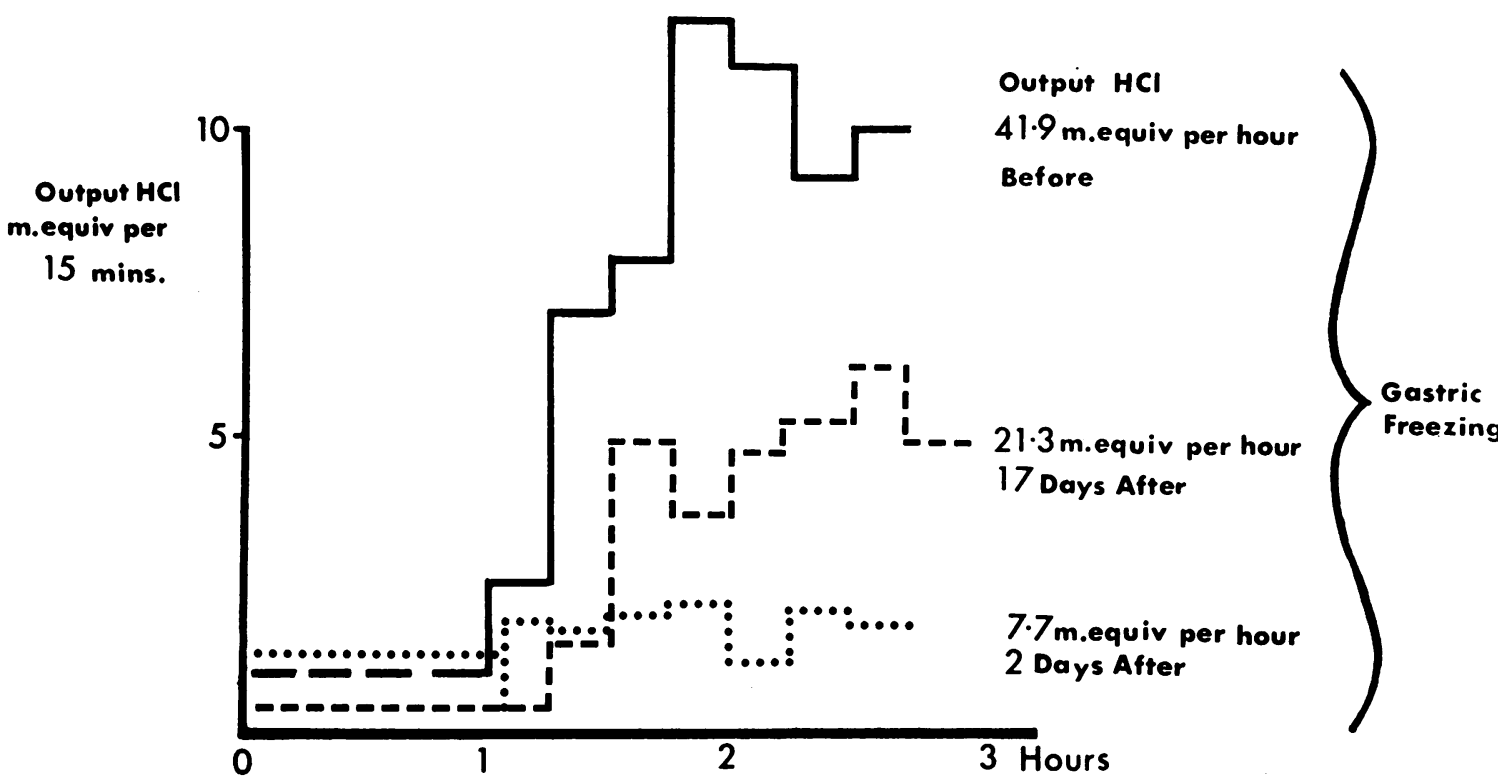

Fig. 9.- Serial histamine infusion tests in patients undergoing gastric freeze. Reproduced by permission of the Editor of the British Journal of Surgery.

maximal secretory response is a valid and reproduceable index of gastric function, irrespective of the stimulus used.

Standardised and pure preparations of gastrin are not yet available commercially, and further definition of the place of this stimulus in the assessment of human gastric secretion must await their supply.

\section{Conclusions}

The output of acid by the human stomach can be estimated simply by the precise quantitative methods commonly used in the laboratory. By using an infusion of histamine acid phosphate as the stimulus a steady state of maximal secretion is achieved and can be measured. It is believed that this test has distinct advantages over the augmented histamine test.

In the light of the development of precise methods of studying gastric secretion the 'test meal' should be abandoned.

These studies were supported by a grant from the Medical Research Council from whom one of us (James H. Lawrie) was in receipt of a full-time grant.

\section{REFERENCES}

Adam, H. M., Card, W. I., Riddell, M. J., Roberts, M., Strong, J. A., and Woolf, B. (1954): Dose Response Curves for the Effect of Histamine on Acid Gastric Secretion in Man, Brit. J. Pharmacol., 9, 329.

BAron, J. H. (1963a): Studies of Basal and Peak Acid Output with an Augmented Histamine Test, Gut, 4, 136.

BARON, J. H. (1963b):

BARON, J. H. (1964): Peptic Ulcer, Gastric Secretion and Body Build, Gut, 5, 83.

BelL, J. R., and MACADAM, W. (1924): The Variation in Gastric Secretion of the Normal Individual, Quart. J. Med., 17, 215.

BenNeTt, T. I., and RYLE, J. A. (1921): Studies in Gastric Secretion V. A Study of Normal Gastric Function Based on the Investigation of One Hundred Healthy Men by Means of the Fractional Method of Gastric Analysis, Guy's Hosp. Rep., 71, 286.

Bergeim, O., Rehfuss, M. E., and Hawk, P. B. (1914): Gastro-intestinal Studies III (Studies on Water Drinking XXI). Direat Demonstration of the Stimulatory Power of Water in the Human Stomach, J. biol. Chem., 19, 345.

BERK, J." E., THomas, J.' E., and ReHFuss, M. E (1942): Limitations in the Use of Colour Indicators in Gastric Analysis, Amer. J. dig. Dis., 9, 106.

Bock, O. A. A. (1962): The Concepts of Free Acid and Total Acid of the Gastric Juice, Lancet, ii, 1101 . 
Bockus, H. L., and BANK, J. (1920): The Value of Histamine as a Test for Gastric Function, Arch. intern. Med., 39, 508.

Callender, S. T., Retief, F. P., and Witts, L. J. (1960): The Augmented Histamine Test with Special Reference to Achlorhydria, Gut, 1, 326.

CARD, W. I., and MARKS, I. N. (1960): The Relationship between the Acid Output of the Stomach Following 'Maximal' Histamine Stimulation and the Parietal Cell Mass, Clin. Sci., 19, 147.

Carnot, P., Koskowski, W., and Liebert, E. (1922): Influence of Histamine on the Digestion Secretion of Man, C.R. Soc. Biol., 86, 575.

ConRad, V., Kowalewski, K., and GeERTRUyden, J. V. (1949): Contribution a l'etude de l'achlorhydrie vraie. Aotion de Doses Croissantes d'Histamine sur la Secretion Gastriques de Malades Proteges par l'Antihistamine, Acta gast. Bull., 12, 545.

EhrmanN, R. R. (1912): Physiologische und Klinische Untersuchungen über die Magensaftsekretion, Int. Beitr. Ther. ErnährStör, 3, 382.

EnTICKNAP, J. B., and Merivale, W. H. (1954): The Value of Clinical Laboratory Tests. VI. The Fractional Test Meal, Guy's Hosp. Rep., 103, 35.

Ewald, C. A., and BoAs, J. (1855-6): Physiol. Path der Verdauung, Virchows Arch., 101, 325; 104271.

Fraser, G. M., Pitman, R. G., LaWrie, J. H., SMith, G. M. R., Forrest, A. P., and RhoDes, J. (1964): The Significance of the Radiological Finding of Coarse Mucosal Folds in the Duodenum, Lancet, ii, 979.

Gregory, R. A., and Tracy, H. J. (1961): The Preparation and Properties of Gastrin, J. Physiol. (Lond.), 156, 523.

GregORY, R. A., and TraCY, H. J. (1964): The Constitution and Properties of Two Gastrins Extracted from Hog Antral Mucosa, Gut, 5, 103.

Grossman, M. I., KirSner, J. B., and Gillespie, I. E. (1963): Basal and Histalog-stimulated Gastric Secretion in Control Subjects and in Patients with Peptic Ulcer or Gastric Cancer, Gastroenterology, 45, 14.

Hirschowitz, B. I., London, J. A., and Wiggins, H. S. (1957): Differential Diagnosis of Gastric Ulcer and Cancer by a Study of Maximally Stimulated Gastric Secretion, J. Lab. clin. Med., 50, 447.

Hitchcock, C. R., Sullivan, W. A., and WangenSTEEN, O. H. (1955): The Value of Achlorhydria as a Screening Test for Gastric Cancer. A 10-year report, Gastroenterology, 29, 621 .

Hollander, F., and PenNer, A. (1939): History and Development of Gastric Analysis Procedure, Amer. J. dig. Dis., 5, 739, 786; 6, 22.

JAMES, A. H. (1957): The Physiology of Gastric Digestion, 192 pp. Monogr. Physiol. Soc., No. 4, London: Edward Arnold.

JAMES, A. H. (1964): Gastric Epithelium in the Duodenum, Gut, 5, 285.

JoHNSON, H. D. (1962): Night Index of Gastric Secretion, Lancet, ii, 583.

JoHNStoN, D. H., and McGraw, B. H. (1958): Gastric Analysis-Evaluation of Collection Techniques, Gastroenterology, 35, 512.

KAST, L. (1906): Experimentelle Beitrage zur Wirkung des Alkohol auf den Magen, Arch. Verdau-Krankh., 12, 487.

KATSCH, G., and KaLK, H. (1924): Chemistry of the Stomach, Arch. Verdau.-Krankh., 32, 201.

KAY, A. W. (1953): Effect of Large Doses of Histamine on Gastric Secretion of $\mathrm{HCl}$. An Augmented Histamine Test, Brit. med. J., i, 77.
KIRSNER, J. B., and FORD, H. (1955): The Gastri@ Secretory Response to Histalog: One-hour Basal and Histalog Secretions in Normal Persons an in Patients with Duodenal Ulcer and Gastric Ulcer? J. Lab. clin. Med., 46, 307.

LAWriE, J. H., SMITH, G. M. R., and Forrest A. P. M. (1964): The Histamine Infusion Test? Lancet, ii, 270.

LaWrie, J. H., SMith, G. M. R., Goodall, $\mathbf{P}$ Pitman, R. G., and Forrest, A. P. M. (1965) Gastric Freezing for Duodenal Ulcer, Brit. J. Surg 52, 226.

Levin, E., Kirsner, J. B., and Palmer, W. Lo (1950): The Continuous 12-hour Nocturnal Gastrie Secretion in Normal Individuals and in Patients with Duodenal Ulcer after a 24-hour Fast. Gastroenterology, 15, 454.

Levin, E., Kirsner, J. B., Palmer, W. L., ang Butler, C. (1948a): Nocturnal Gastric Secretion' Studies on Normal Subjects and on Patients wit Duodenal Ulcer, Gastric Ulcer and Gastrie Carcinoma, Arch. Surg., 56, 345.

Levin, E., KIRSNer, J. B., PAlMer, W. L., and BuTler, C. (1948b): The Variability and Periodicity of the Nocturnal Gastric Secretion in Normal Individuals, Gastroenterology, 10, 939.

LEUBE, v. (1876): Bemerkungen über die Ablösung der Magenscheleimhaut durch die Magensonde und Ihre Folgen, Dtsch. Arch. $F_{\text {. }}$ Klin. med., 18, 496.

Makhlouf, G. M., MoManus, J. P. A., and Carr W. I. (1964a): Dose Response Curves for the Effect of Gastrin II on Acid Secretion in Mañ Gut, 5, 379 .

Makhlouf, G. M., McManus, J. P. A., and CAD, W. I. (1964b): Demonstration to British Socest of Gastroenterology, Postgraduate Medical Schopg November, 1964.

Marks, I. N., Komarov, S. A., and ShaY, H. (1960) Maximal Acid Secretory Response to Histamine and its Relation to Parietal Cell Mass in the Dog Amer. J. Physiol., 199, 579.

MARKS, I. W., and SHAY, H. (1960): Augmente Histamine Test, Ewald Test Meal and Diagne Test. Comparison of Results, Amer. J. dig. Dis 5, 1.

MARKS, I. W. (1961): The Augmented Histaminè Test. Editorial, Gastroenterology, 41, 599.

Michaelis, L. (1926): Some Problems Concerning the Gastric Juice. In The Harvey Lectures 1926p. 59, Baltimore: Williams and Wilkins.

Polland, W. S. (1933): Histamine Test Meal. AB Analysis of Nine Hundred and Eighty-eight Con secutive Tests, Arch. intern. Med., 51, 903.

PollaND, W. S., and BlOOMFIELD, A. L. (1931) 옹 Normal Standards of Gastric Function, J. clin Invest., 9, 651 .

PoPIELSKI, L. (1920): Uber die Physiologischen un Chemischen Eigenschaften des Peptons Witte, Pflus Arch. Ges. Physiol., 126, 483.

Prout, W. (1824): On the Nature of the Acid and Saline Matters Usually Existing in the StomachS of Animals, Philos. Trans. Part 1, p. 45.

REHFUSS, M. E. (1914): A New Method of Gastris Testing with a Description of a Method for the Fractional Testing of the Gastric Juice, Amer. 西 med. Sci., 147, 848.

REHFuSS, M. E. (1927): Diagnosis and Treatment of Diseases of the Stomach, p. 1236, Philadelphia W. B. Saunders.

Rhodes, J., Apsimon, H. T., and LAwrie, J. $\mathbf{P}$ (1965): The pH of the Contents of the Duodeng 
Bulb in Relation to Duodenal Ulcer. (In preparation).

Rivers, A. B., Osterberg, A. E., and Vanzant, F. R. (1936): The Double Histamine Test as Aid to the Study of Gastric Secretory Function, Amer. J. dig. Dis., 3, 12.

RovelstaD, R. A. (1963): Gastric Analysis, Gastroenterology, 45, 90.

Sandweiss, D. J., Friedman, M. H. F., Sugarman, M. H., and PoDolsKy, H. M. (1946a): Nocturnal Gastric Secretion. II. Studies on Normal Subjects and Patients with Duodenal Ulcer, Gastroenterology, $7,38$.

Sandweiss, D. J., Sugarman, M. H., Podolsky, H. M., and FrIEDMAN, M. H. F. (1946b): Nocturnal Gastric Secretion in Duodenal Ulcer; Studies on Normal Subjects and Patients, with their Bearing on Ulcer Management, J. Amer. med. Ass., 130, 258.
SIRCUS, W. (1962): Lessons from the Zollinger-Ellison Syndrome. Surgical Physiology of the Gastrointestinal Tract. Edited by A. N. Smith, p. 92. The Royal College of Surgeons of Edinburgh.

Vanzant, F. R., Alvarez, W. C., Eusterman, G. B. DuNN, H. L., and BERKSON, J. (1932): The Normal Range of Gastric Acidity from Youth to Old Age, Arch. intern. Med., 49, 345.

Wangansteen, O. H., Peter, E. T., Nicoloff, D. N., WAlder, A. I., SOSIN, H., and BERNSTEIN, E. F. (1962): Physiological Gastrectomy by Gastric Freezing: Preliminary Report of Experimental and Clinical Study, J. Amer. med. Ass., 180, 439.

Ward, S., Gillespie, I. E., Passaro, E. P., and Grossman, M. I. (1963): Comparison of Histalog and Histamine as Stimulants for Maximal Gastric Secretion in Human Subjects and in Dogs, Gas troenterology, 44, 620 . 